\title{
Bioethics, semiotics of life, and global communication
}

\author{
Augusto Ponzio, Susan Petrilli \\ Dipartimento di Pratiche Linguistiche e Analisi di Testi, \\ University of Bari, Via Garruba 6, 70100 Bari, Italy \\ e-mail: s.petrilli@lingue.uniba.it
}

\begin{abstract}
Ethical problems connected with biological and medical discoveries in genetic engineering, neurobiology and pharmaceutical research, reach a unified and critical point of view in bioethics as a specific discipline. But even before reaching this stage, ethical problems already belong to two totalities: the semiobiosphere, and the current social form of global communication. Coherently with its philosophical orientation, bioethics must necessarily keep account of this double contextualisation. The semiobiosphere is the object of study of global semiotics or the semiotics of life. Global semiotics is of particular interest to bioethics not only because of the broad context it provides for the problems treated by bioethics, but also because it provides bioethics with an adequate contextualisation both in terms of extension, of quantity, as well as of quality. From this point of view, "contextualisation" also means critical reformulation. We are now alluding to the need of viewing bioethical problems in the light of today's socio-economic context, that is, in the context of global communication-production. These contextualisations are closely related from the viewpoint of ethics. Semiotics as global semiotics or semiotics of life must accept the responsibility of denouncing incongruencies in the global system, any threats to life over the entire planet inherent in this system.
\end{abstract}

Bioethics offers a unified and critical perspective for ethical problems connected with biological and medical discoveries in the fields of genetic engineering, neurobiology and pharmaceutical research, etc. With the introduction of bioethics such ethical problems become the object of study of a specific discipline.

However, ethical problems, even before the introduction of this new discipline, are already part of two totalities which together contribute to their characterisation: one totality is the semiobiosphere; the 
other is today's society of global or world communication. Bioethics, coherently with its philosophical orientation which is critical and foundational, must necessarily keep account of this double contextualisation when dealing with the problems at the centre of its attention.

The focus of global semiotics or what we may also call semiotics of life is the whole semiobiosphere.

Thomas A. Sebeok above all has contributed to the current status of this discipline or "doctrine of signs". Rather than the more ennobling terms "science" or "theory", Sebeok prefers the expression "doctrine of signs" adapted from John Locke - for whom a doctrine is a body of principles and opinions vaguely forming a field of knowledge, and with this expression Sebeok takes his place in a tradition that includes Berkeley and leads to Charles S. Peirce.

Like Kant, Peirce focusses on signifying conditions. This leads to the possibility of identifying foundations shared by the human sciences and the natural sciences. Thanks to Peirce's "doctrine of the categories" the two opposite conceptions of reality which have dominated Western philosophical thought at last meet. We are alluding to the conception of reality which originates from Aristotle, on the one hand, and recites that things exist on their own account and independently from mind, and to the opposite conception which describes reality as depending on mind, on the other. The point of encounter is the semiotic perspective which describes objects and minds as part of the common process of semiosis.

The expression "doctrine of signs" also evidences the pedagogical character of Sebeok's research - but not only. With this expression Sebeok recovers the critical instance of semiotics. From this point of view not only does semiotics assign itself the task of observing and describing sign processes, but even more than this it interrogates itself à la Kant on the conditions of possibility of sign processes, just as it interrogates the conditions of possibility of the disciplines themselves that study sign processes.

As stated above, the object of global semiotics, of semiotics of life, is the semiosphere. This term is taken from Lotman but is understood in a more extended sense. In fact the Lotman refers the term "semiosphere" to human culture, while in the perspective of global semiotics the semiosphere identifies with the biosphere and may be characterised as the semiobiosphere: in fact semiosis coincides with life and in this sense global semiotics is "semiotics of life"). Global semiotics is in a position to evidence the extension and consistency of the sign network which obviously includes the semiosphere as constructed by 
human beings, by human culture, signs, symbols and artifacts, etc. But global semiotics also underlines the fact that the semiosphere is part of a far broader semiosphere, the semiobiosphere - a sign network human beings have never left, and to the extent that they are living beings, never will.

With reference to Sebeok's writings the most systematic exposition of global semiotics is offered by the Italian edition of his book of 1991, A Sign is just a Sign: La semiotica globale (1998), which in addition to the original edition includes his essay of 1994 "La semiotica globale". Another book by Sebeok is scheduled to appear in 2001 entitled Global semiotics.

At an international level the most systematic work in global semiotics is without a doubt Semiotics: A Handbook on the Sign-Theoretic Foundations of Nature and Culture, in three volumes (the third is forthcoming), edited by R. Posner, K. Robering and Thomas A. Sebeok. This volume has benefited from the participation of 175 authors from 25 different nations. It includes, among others, an article by Sebeok "The evolution of semiosis" (published in Italian translation in his volume of 1998 cited above) in which he claims that life and semiosis coincide. This Handbook also includes many other articles referring to different fields and interests covered by global semiotics, these include: biosemiosis (Th. von Uexküll), microsemiosis (F. E. Yates), endosemiosis (T. von Uexküll and W. Geiges), mycosemiosis (G. Kraepelin), phytosemiosis (M. Krampen), zoosemiosis (W. Schler), anthroposemiosis (F. M. Wuketits), semiosis of machines (P. B. Andersen, P. Hasle, P. A. Brandt), environmental semiosis (G. Tembrock).

Global semiotics or semiotics of life is particularly significant for bioethics because of the broad context it provides for the problems at the centre of its attention (though this is not the only reason). And in fact, given that in the perspective of global semiotics semiosis and life coincide, the context is far broader than that postulated by Saussure's semiology which studies signs in the sphere of social life.

On his part, Sebeok closely relates anthroposemiotics to zoosemiotics (the study of animal communication including nonverbal human signs) and to endosemiotics (the study, on both the ontogenetic and the phylogenetic levels, of cybernetic systems within the organic body). In Sebeok's view, biological and therefore biosemiotic foundations are the epicentre for studies on communication and signification processes in the human animal. Sebeok's semiotics unites what in other fields of knowledge and praxis is generally kept apart in the ef- 
fort to justify needs of a specialized order, but also for the sake of useless and even damaging sectorialisations. This tendency is not devoid of ideological implications though often masked by motivations of a scientific order, and poorly so.

However, that global semiotics can provide bioethics with an adequate contextualisation is not only true in terms of extension, of quantity; a qualitative aspect is also involved. From this point of view "contextualisation" means critical founding. Global semiotics contributes to a foundational and critical approach to bioethics, that is, to its characterisation as a theoretical-philosophical discipline.

In fact the approach adopted by global semiotics is predominantly of an ontological order. Global semiotics refers explicitly to both Peirce's and Morris's semiotics as signposts, and no doubt their approaches are very broad - we know that Peirce went so far as to maintain that the whole universe is perfused with signs, if not made entirely of signs. However, beyond Peirce and Morris who limit their work to the phenomenological description of the various processes that may be interpreted as semiosical, Sebeok with global semiotics contributes to the reformulation of ontology in semiotic terms.

Sebeok's global semiotics interrogates itself on being, and does so from the point of view of life, for, as says Heidegger, the question of being is inevitably the question of that particular being for whom that question is vital. Indeed, not only is it a question of the life of the human individual or of all humanity, but also of life over the whole planet given the social system dominant today, that of global communication, and given, therefore, not only the pervasiveness but also the destructive potential of presentday anthroposemiosis. Global semiotics answers the ontological question by identifying life and semiosis.

With his global semiotics Sebeok may be considered as the author of such an ontological perspective, and of its diffusion among semioticians and cryptosemioticians. And all the different specialized contributions offered by those scholars who have contributed with different disciplinary competencies to the monumental Handbook take their place, whether consciously or unconsciously, in this particular setting. From this point of view, the Handbook in question is an official recognition of the status of Sebeok's global semiotics and of the accomplishment of his project. On the other hand, bioethics cannot ignore the benefits it may receive for its own philosophical vocation from global semiotics. And this is so not only because of the scientific analyses conducted by global semiotics in the different fields of biosemiosis on a phenomenological level, but above all because the ap- 
proach adopted by global semiotics as semiotics of life is primarily of an ontological order.

Global semiotics starts from the hypothesis that semiosis and life coincide and focusses on the interconnection among signs. Its gaze moves from the protosemiosis of energy-information to the overall processes of the complexification of semiosis in the evolution of life over the planet: from prokaryotes to monocellular living beings to the eukaryotic aggregates which form the multicellular organisms belonging to the superkingdoms. The latter coexist and interact with the microcosm and together form the great semiobiosphere. All this results in an indissoluble interconnection as presented by the network of signs: in Sebeok's words, this network extends from the Lilliputian world of molecular genetics and virology, to the man-size world of Gulliver and finally to the world of Brobdingnag, the gigantic biogeochemical ecosystem called Gaia. At first sight this system may seem to be made of numerous separate living species, but, at a closer look, we soon realize that each one of its parts, ourselves included, is interdependently connected with all the others. This system taken wholly, so to say, is the only ecosystem which may really be considered as such (even though it too only relatively).

As mentioned at the beginning, in addition to contextualisation of the phenomenological and ontological orders provided by global semiotics, another kind of contextualisation is also necessary for an adequate treatment of problems relevant to bioethics. We are now referring to the need of viewing bioethical problems in the light of today's socio-economic context, that is, in the context of global communication-production.

Such contextualisations are closely related and are so from the viewpoint of ethics. In fact, if we consider the contribution made by global semiotics to bioethics in relation to presentday global communication, semiotics is faced with an enormous responsibility, that of evidencing the limits of today's communication-production society. Semiotics must now accept the responsibility of denouncing incongruencies in the global system with the same energy, instruments and social possibilities produced by the global communication-production system itself. Semioticians must now be ready to denounce the dangers inherent in this system for life over the entire planet.

Today's phase in the development of the capitalistic system is that of "global communication". This expression may be understood in at least two senses: that communication is now characterised by its $e x-$ tension over the whole planet and that it is accomodated realistically 
to the world as it is. Globalisation implies the omnipresence of communication in production and characterises the entire productive cycle: not only is globalisation present at the level of the market, of exchange, as in earlier phases in socio-economic development, but also at the level of production and consumption. Globalisation is tantamount to heavy interference by communication-production not only in human life but in life in general over the whole planet.

For an understanding of world-wide global communicationproduction we need a view that is just as global. While the special sciences taken separately are not in a position to provide such a global view, the general science of signs or semiotics as it is taking shape today on the international scene thanks to the approach fostered by Sebeok and his ongoing work for further development, is.

A full understanding of global communication today implies a full understanding of the risks involved by global communication, including the risk of the end of communication itself. This risk, however, is not simply that of the rather banal phenomenon known as "incommunicability", theorized and represented in film and literature. What we are alluding to, instead, is the subjective-individualistic disease provoked by the transition to communication in its current forms (and which can no longer be separated from production). When we speak of the "risk of the end of communication", we are referring above all to the recognised identification between communication and life, and therefore to the risk of the end of life on the planet, considering the enormous potential for destruction in today's society by contrast with all other earlier phases in the development of the social system.

Therefore, the expression global communication-production does not only refer to the expansion of communication means and of the market at a world-wide level, but also to the fact that all human life is incorporated into the communication-production system: whether in the form of development, well-being and consumerism or of underdevelopment, poverty and the impossibility to survive; health or sickness; normality or deviation; integration or emargination; employment or unemployment; transfer functional to the work-force characterising emigration or transfer of peoples in their denied request of hospitality, characteristic of migration; the traffic and use of legal commodities or of illegal goods, from drugs to human organs, to "non-conventional" weapons. Indeed, this process of incorporation is not limited to human life alone. All of life over the entire planet is now irremediably involved (even compromised and put at risk) in the communicationproduction system. 
Reflection on problems relevant to bioethics today in the context they in fact belong to, the context of globalisation, requires an approach therefore that is just as global. An approach which does not simply consider partial and sectorial aspects of the communicationproduction system according to internal perspectives functional to the system itself, an approach which is not limited on an empirical level to psychological subjects, to subjects reduced to the parameters imposed by the social sciences - subjects measurable in terms of statistics. Global communication-production calls for a methodological and theoretical perspective just as global as the phenomenon under observation, a perspective in a position to understand the logic of global communication-production and to proceed therefore to a critique of the system it subtends.

An adequate analysis of today's world of global communication in all its complexity calls for conceptual instruments which must be as precise as possible, and which a new theory of communication may furnish; these conceptual instruments must also be as rigorous as possible and this can only be provided through a philosophical grounding of such a theory. An attempt in this sense is made in the volume by Ponzio, La comunicazione (1999) as well as in the volume coauthored by Ponzio and Petrilli, Il sentire nella comunicazione globale (2000).

Social reproduction in the global communication-production system is destructive. Reproduction of the productive cycle itself is destructive. It destroys: (a) machines, which are continuously substituted with new machines - not because of wear but for reasons connected with competitivity; (b) jobs, making way for automation which leads to an increase in unemployment; (c) products on the market where new forms of consumerism are elicited, completely ruled by the logic of reproducing the productive cycle; (d) earlier products which once purchased would otherwise exhaust the demand and which in any case are designed to become immediately outdated and obsolete as new and similar products are continuously introduced on the market; (e) commodities and markets which are no longer able to resist competition in the global communication-production system.

It is no incident that the European Commission which has devoted special attention to inventiveness and innovation functional to profit, to "immaterial investment" and "competitivity" (cf. Green book on innovation, 1995), should identify "innovation" with "destruction" in full respect of capitalistic ideologic. The innovative character of a product is made to consist in its capacity for destruction: this product 
must destroy earlier products that are similar and still present on the market. The capacity for innovation abreast of the times coincides with the capacity for destruction to the extent that the criteria for evaluating innovation are completely adjusted to the interests of the market.

The conatus essendi of communication-production destroys natural environments and life forms. It also destroys different economies and cultural differences which in fact tend to be eliminated by the processes of homologation operated by market logic: nowadays not only are habits of behaviour and needs rendered identical (though the possibility of satisfying such needs is never identical), but even desires and the imaginary tend to be homologated. The conatus essendi of communication-production also destroys traditions and cultural patrimonies that contrast with or obstacle or are simply useless, non functional to the logic of development, productivity and competition. It destroys those productive forces that tend to escape the limits of current forms of production which penalize intelligence, inventiveness and creativity by over-ruling them and subjecting them to "market reason" (and of course production cannot avoid this in the current phase of necessary investment in "human resources"). The destructive character of today's production system is also manifest in the fact that it produces growing areas of underdevelopment as the very condition of development, areas of human exploitation and misery to the point of nonsurvival. This logic subtends the expanding phenomenon of migration which so-called "developed" countries are no longer able to contain due to objective internal space limitations - no doubt greater than in earlier forms and phases in the development of the social system.

Universalisation of the market, that is, application of the status of commodities to all things and relationships, is destructive; and the more so-called commodities are illegal and prohibited - think of drugs, human organs, children, uteruses, etc. - the more they are expensive. The principle of exploiting other people's work is destructive, work obviously costs less the more it produces profit: with the help of global communication developed countries are more and more turning to low cost work in underdeveloped countries ("stay where you are, and we'll bring you work"). The disgrace of the communication-production world is particularly manifest in the spreading exploitation of child labour that is heavy and even dangerous (much needs to be said and done about children as today's victims of underdevelop- 
ment, in misery, in sickness, in war, on the streets, in the work-force, on the market).

The destructive character of world-wide communication-production is also made obvious by war which is always a scandal. Global communication-production is the communication-production of war. War requires continuously new markets for the communicationproduction of conventional and unconventional weapons. War also requires increasing approval acknowledging it as just and necessary, as a necessary means of defense against the growing danger of the menacing "other", as a means therefore of achieving respect for the rights of one's "own identity", "one's own difference". The truth is that identities and differences are not threatened or destroyed by the "other", but by today's social system itself which encourages and promotes identity and difference while rendering them fictitious and phantasmal. And this is precisely the reason why we cling to such values so passionately, a logic which fits the communicationproduction of war to perfection.

With the spread of "bio-power" (Foucault) and the controlled insertion of bodies into the production apparatus, world communication goes hand in hand with the spreading of the concept of the individual as a separate and self-sufficient entity. The body is understood and experienced as an isolated biological entity, as belonging to the individual, as a part of the individual's sphere of belonging. This has led to the quasi total extinction of cultural practices and worldviews based on intercorporeity, interdependency, exposition and opening of the body (what remains is the expression of a generalized tendency to museumification; mummified remains studied by folklore analysts, archeological remains preserved in ethnological museums and in the histories of national literatures).

The technologies of separation as applied to human bodies, to interests, to the life of individual and collective subjects are functional to production and to identification of production and consumption characteristic of present day production forms. With respect to all this and thanks to its ontological perspective, global semiotics (or semiotics of life) can, if nothing else, oppose a whole series of signs showing how each instant of individual life is wholly interrelated, even compromised with all other forms of life over the entire planet.

To acknowledge such interrelatedness, such compromise involves a form of responsibility which far exceeds all positive rights and all limited responsibilities, restricted responsibilities with alibis. Such acknowledgement is ever more urgent the more the reasons of produc- 
tion and of global communication functional to it impose ecological conditions which impede and distort communication between our bodies and the environment.

An ontological reformulation of bioethics on the basis of the semiotics of life and keeping account of the current socio-economic context of global communication helps single out two fundamental principles: dispossession and extralocalisation. These principles allude to the human individual as a living body interconnected with all other forms of life over the whole planet thanks to its condition of diachronic and synchronic intercorporeity: dispossession with respect to techniques favouring the body's subordination to the knowledgepower of biopolitics (Foucault); extralocalisation with respect to chronotopic coordinates, projects, structures and roles functional to reproduction in the economico-social form of global communication.

Dispossession and extralocalisation are manifest in the body's "escape without rest" from the techniques that wish to dominate and control it, and above all in its "persistence in dying". Dispossession and extralocalisation are principles that must be taken into account in the prolegomena for an approach to bioethics that is critical, philosophical and theoretical, this being the condition for acknowledgement of their moral and juridical status.

\section{References}

Benjamin, Walter et al. 1995. Il carattere distruttivo. (Millepiani 4.) Milano: Mimesis.

Foucault, Michel 1972. L'ordine del discorso. Turin: Einaudi.

- 1992a. Tecnologie del sé. In: Martin, L.H.; Gutman, H.; Hutton, P.H. (eds.), Tecnologie del sé: Un seminario con Michel Foucault. Torino: Bollati Boringhieri, 11-47.

- 1992b. La tecnologia politica degli individui. In: Martin, L.H.; Gutman, H.; Hutton, P.H. (eds.), Tecnologie del sé: Un seminario con Michel Foucault. Torino: Bollati Boringhieri, 135-153.

- 1994a. Poteri e strategie: L'assoggettamento dei corpi e l'elemento sfuggente. Milano: Mimesis.

${ }^{1}$ Together with the University of Bari, Italy, we wish to thank the Director of the Istituto Italiano di Cultura in Frankfurt am Main, Germany, Dr. Luigi Volta, who financed our participation at the Conference The Semiotic Threshold from Nature to Culture, at the Research Centre for Cultural Studies of the University of Kassel, 16-17 February, 2001. 
- 1994b. Eterotopia: Luoghi e non luoghi metropolitani. (Millepiani 2.) Milano: Mimesis.

- 1996. Biopolitica del potere: I rapporti di potere passano attraverso i corpi. (Millepiani 9.) Milan: Mimesis.

Heidegger, Martin 1976. Essere e tempo. Trans. by P. Chiodi. Milano: Longanesi. Lotman, Jurji M. 1985. La semiosfera. Venice: Marsilio.

Morris, Charles 1998. Lineamenti di una teoria dei segni. Lecce: Piero Manni.

- 2000. Significazione e significatività. Trans. and ed. by Susan Petrilli. Bari: Graphis.

Peirce, Charles S. 1980. Semiotica: i fondamenti della semiotica cognitiva. Selected and introduced by M. A. Bonfantini, L. Grassi, R. Grazia. Turin: Einaudi.

Petrilli, Susan 1995a. Materia segnica e interpretazione. Lecce: Milella.

- 1995b. Che cosa significa significare? Bari: Edizioni dal Sud.

- 1998a. Su Victoria Welby. Significs e filosofia del linguaggio. Napoli: Edizioni Scientifiche Italiane.

- 1998b. Teoria dei segni e del linguaggio. Graphis: Bari.

Petrilli, Susan; Ponzio, Augusto 1998. Signs of research on signs. Semiotische Berichte 22(3/4): 5-173.

Petrilli, Susan; Ponzio, Augusto 1999. Fuori campo: I segni del corpo tra rappresentazione ed eccedenza. Milan: Mimesis.

Ponzio, Augusto 1995. La differenza non indifferente: Comunicazione, migrazione, guerra. Milan: Mimesis.

- 1997. Elogio dell'infunzionale: Critica dell'ideologia della produttività. Rome: Castelvecchi.

- 1999. La comunicazione. Bari: Graphis.

Ponzio, Augusto; Petrilli, Susan 2000. Il sentire della comunicazione globale. Rome: Meltemi.

Posner, Roland; Robering, Klaus; Sebeok, Thomas A. (eds.) 1997-1998. Semiotics: A Handbook on the Sign-Theoretic Foundations of Nature and Culture, vol. 1-2. Berlin: de Gruyter.

Prodi, Giorgio 1977. Le basi materiali della significazione. Milano: Bompiani.

Sebeok, Thomas A. 1976. Contributi alla dottrina dei segni. Milan: Feltrinelli.

- 1984. Il gioco del fantasticare. Milan: Spirali.

- 1985. Il segno e i suoi maestri. S. Petrilli (ed.). Bari: Adriatica,

- 1990. Penso di essere un verbo. S. Petrilli (ed.). Palermo: Sellerio.

- 1992. Sguardo sulla semiotica americana. S. Petrilli (ed.). Milano: Bompiani.

- 1998a. Come comunicano gli animali che non parlano. S. Petrilli (ed.). Bari: Edizioni dal Sud.

- 1998b. The sign is just a sign. La semiotica globale. S. Petrilli (ed.). Milano: Spirali.

- 2001. Global semiotics. Bloomington: Indiana University Press.

Sebeok, Thomas A.; Petrilli, Susan 1999. Women in semiotics. In: Carr, Gerald F.; Harbert, Wayne; Zhang, Lihua (eds.), Interdigitations: Essays for Irmengard Rauch. New York: Peter Lang, 469-478.

Sebeok, Thomas A.; Umiker-Sebeok, Jean (eds.) 1992. Biosemiotics: The Semiotic Web 1991. Berlin: Mouton de Gruyter. 
Uexküll, Jakob von 1967. Ambiente e comportamento. Introduction by F. Mondella. Milano: Il Saggiatore.

Welby, Victoria 1990. Senso, significato, significatività. Idee: Genesi del Senso 13/15: $145-154$.

\section{Биоэтика, семиотика жизни и глобальная коммуникация}

Этические проблемы, связанные с биологическими и медицинскими открытиями в сфере генной технологии, нейробиологии и фармацевтических исследований достигают стадии объединения в биоэтике как самостоятельной дисциплине. Но еще до достижения этой стадии этические проблемы принадлежат к двум целостным группам: одна из них - семиобиосфера, а вторая - современная социальная форма глобальной коммуниксици. В соответствии с этим биоэтика должна учитывать двойную контекстуализацию исследуемых проблем. Семиобиосфера является объектом глобальной семиотики или семиотики жизни. Глобальная семиотика представляет особый интерес для биоэтики не только благодаря широте контекста, который та предоставляет для решения проблем, разрабатываемых в биоэтике, но и потому, что глобальная семиотика обеспечивает биоэтику адекватной контекстуализацией как в отношении экстенсивности, количества, - так и в отношении качества. С этой точки зрения "контекстуализация" означает и критическое переосмысление. Очевидной становится необходимость рассмотрения биоэтических проблем с учетом современного социоэкономического контекста, т.е. контекста глобального процесса коммупикаипи-производства. С точки зрения этики эти две возможности контекстуализации тесно переплетаются. Современная семиотика в качестве глобальной семиотики или семиотики жизни должна взять на себя ответственность за обнаружение несоответствий в глобальной системе, всех опасных для жизни явлений, присущих этой охватывающей планету системе. 


\section{Bioeetika, elusemiootika ja globaalne kommunikatsioon}

Geenitehnoloogia, neurobioloogia ja farmaatsia vallas tehtud bioloogiliste ja arstiteaduslike avastustega seotud eetilised probleemid puutuvad kokku ühes olulises punktis - bioeetikas. Bioeetikas saavad eetilistest probleemidest iseseisva distsipliini uurimisobjektid. Aga isegi enne sellele tasemele jõudmist kuuluvad eetilised probleemid kahte tervikusse, mis koos loovad selliste probleemide alusjooned: üks neist on semiobiosfääri terviklikkus; ja teine sotsiaalse kommunikatsiooni globaalselt toimiv vorm. Vastavalt oma aluspõhisele ja kriitilisele filosoofilisele orientatsioonile peab bioeetika arvestama uuritavate probleemide kahekordse kontekstualiseeritusega. Semiobiosfäär on globaalse semiootika või elusemiootika uurimisobjekt. Bioeetikat huvitab eriti viimane, ning seda mitte üksnes konteksti avaruse tõttu, mida see pakub bioeetika poolt käsitletavatele probleemidele. Globaalsemiootika pakub bioeetikale sobivat kontekstualiseerimisvõimalust, mitte üksnes ulatuse ja kvantiteedi, vaid ka kvaliteedi osas. Sellest vaatekohast tähendab "kontekstualiseerimine" ka kriitilist ümbersõnastamist. Globaalsemiootika on bioeetikale vajalik aluspõhise ja kriitilise lähenemise jaoks. Lisaks globaalsemiootika pakutavale kahekordsele kontekstualiseeritusele, nii fenomenoloogilisele kui ontoloogilisele, on bioeetikale tähtsate probleemide kohaseks käsitlemiseks vajalik ka teistsugune kontekstualiseerimine. Siinkohal viitame vajadusele vaadelda bioeetilisi probleeme tänapäeva sotsiaal-majanduslikus, st globaalse kommunikatsiooni tootmise valguses. Eetika seisukohalt on need kaks kontekstualiseerimisvõimalust omavahel tihedalt seotud. Tegelikult peabki tänapäeva semiootika globaal- või elusemiootikana võtma endale kohustuse taunida ühtimatusi globaalses süsteemis ja kõiki elu ähvardavaid ohte, mis sellest planeeti hõlmavast süsteemist vältimatult tulenevad. 